\title{
PENGARUH TINGKAT KONSUMSI ENERGI, PROTEIN, LEMAK, DAN STATUS KECACINGAN TERHADAP STATUS GIZI PADA SISWA SEKOLAH DASAR NEGERI O1 LIMPAKUWUS
}

\section{THE EFFECT OF ENERGY, PROTEIN, FAT CONSUMPTION RATE AND WORM INFECTIONAL STATUS TO THE SDN 01 LIMPAKUWUS STUDENT'S NUTRITIONAL STATUS}

\author{
Rendy Manuhutu', Dyah Umiyarni Purnamasari ${ }^{2}$, dan Endo Dardjito ${ }^{1}$ \\ ${ }^{1}$ BPJS Kesehatan KLOK Cilegon Jurusan Kesehatan Masyarakat Fakultas Ilmu- \\ ilmu Kesehatan \\ Universitas Jenderal Soedirman \\ E-mail: rendy.unsoed@gmail.com
}

\begin{abstract}
ABSTRAK
Usia sekolah merupakan periode penting kehidupan manusia dan kualitasnya harus dipersiapkan dengan baik. Anak usia sekolah rentan terkena gizi buruk. Malnutrisi di kalangan anak usia sekolah akan mempengaruhi perkembangan anak dan pengembangan potensi lebih lanjut di usia tersebut. Tingkat konsumsi makanan dan status infeksi cacing adalah dua faktor yang paling mempengaruhi status gizi sekolah anak-anak. Tujuan dari penelitian ini adalah untuk mengetahui pengaruh status influensa energi, protein, lemak dan cacing terhadap status gizi siswa SDN 01 Limpakuwus di Sumbang, Banyumas. Penelitian ini merupakan pendekatan cross sectional study, menggunakan purposive sampling dengan kriteria inklusi dan eksklusi pada 44 responden. Analisis dilakukan secara univariat, bivariat (rank Spearman) dan multivariat (multiple logistic regression). Analisis multivariat menunjukkan variabel yang mempengaruhi status gizi adalah tingkat konsumsi lemak $(\mathrm{p}=0,022)$, dan variabel tidak mempengaruhi status gizi adalah tingkat konsumsi energi $(p=0,999)$, tingkat konsumsi protein $(p=0,580)$, dan status infeksi cacing $(\mathrm{p}=0,661)$. Sarannya adalah untuk mendapatkan lebih banyak makanan yang bisa memenuhi kebutuhan energi, protein, lemak dan membuat kantin di sekolah menjadi kantin sehat yang menyajikan makanan sehat dan bergizi.

Kata kunci: Tingkat Konsumsi, Helminthiases, Status Gizi, Sekolah Berumur-Anak
\end{abstract}

\begin{abstract}
School age is the important period of human life and the quality have to be prepared well. The school age children is susceptible to malnutrition. Malnutrition among school age children will implicate the children's development and further potential development in that age. Food consumption levels and worm infection status are the two most affected factors to nutritional status of children school. The purpose of this research is to know the effect of energy, protein, fat and worm inflectional status to the nutritional status of SDN 01 Limpakuwus's student in Sumbang, Banyumas. This research was cross sectional study approach, used purposive sampling with inclusion and exclusion criteria in 44 respondents. Analysis conducted by univariate, bivariate (Spearman rank) and multivariate (multiple logistic regress ion). Multivariate analysis showed the variables that influenced nutritional status is the level of fat consumption $(\mathrm{p}=0.022)$, and the variable did not affect the nutritional status are the level of energy consumption $(\mathrm{p}=0.999)$, protein consumption level $(\mathrm{p}=0.580)$, and worm infection status $(\mathrm{p}=0.661)$. The suggestion is to get more food that can fulfil the energy, protein, fat needs and make the canteen in the school becomes a healthy canteen that serves healthy and nutritious meal.Keywords: Consumption Rate, Helminthiases, Nutritional Status, School Aged-children
\end{abstract}




\section{PENDAHULUAN}

Faktor gizi memegang peranan yang sangat penting dan merupakan salah satu faktor penentu dalam keberhasilan Pembangunan Nasional. Pendekatan upaya perbaikan gizi diperlukan pada seluruh siklus kehidupan manusia mulai sejak janin dalam kandungan, bayi, balita, usia sekolah, remaja, dewasa sampai usia lanjut. Salah satu siklus kehidupan manusia yang terpenting yaitu pada anak usia sekolah. Kekurangan gizi pada usia sekolah akan berimplikasi pada perkembangan anak dan selanjutnya perkembangan potensi diri pada usianya (Kemenkes, 2013).

Berdasarkan data Riskesdas (2013), prevalensi kurus (menurut IMT/U) pada anak usia 5-12 tahun di Indonesia adalah 11,2\%, dimana Provinsi Jawa Tengah termasuk dalam 16 provinsi dengan prevalensi sangat kurus diatas rata-rata nasional yaitu sekitar 13\%. Selain tingginya prevalensi kurus pada anak usia 5-12 tahun. Banyumas adalah salah satu kabupaten di Provinsi Jawa Tengah dengan kasus wasting yang tinggi. Berdasarkan data Dinkes Banyumas (2014), bahwa terdapat 7,4\% kasus wasting pada anak usia sekolah dasar yang ada di 39 wilayah puskesmas. Hal ini didukung juga oleh penelitian yang dilakukan oleh Purnamasari dkk (2014), pada 4 sekolah dasar di Kabupaten Banyumas sebanyak 7,4\% anak menderita wasting.

Menurut UNICEF (1998), faktorfaktor yang mempengaruhi status gizi ada dua yaitu faktor langsung dan faktor tidak langsung. Faktor langsung yang mempengaruhi status gizi ialah tingkat konsumsi makanan dan penyakit infeksi. Anak yang kurang mendapat asupan makanan akan berakibat menurunnya kekebalan tubuh (imunitas), sehingga mudah terserang panyakit infeksi, kurang nafsu makan dan akhirnya mudah terkena gizi kurang (Waryana, 2010). Kemenkes (2013) menyebutkan prevalensi kecacingan masih relatif tinggi yaitu sebesar 28\%. Faktor penyebab lain menurut UNICEF (1998), yang dapat mempengaruhi status gizi adalah tingkat konsumsi makanan. Hasil penelitian Pahlevi (2012), yang dilakukan di SD 02 Ngesrep Banyumanik, Semarang menunjukkan adanya hubungan antara status gizi dan tingkat konsumsi energi dan adanya hubungan antara status gizi dan tingkat konsumsi protein.

Kabupaten Banyumas memiliki kasus wasting/kurus yang tinggi pada anak. Berdasarkan hasil penjaringan kesehatan 
peserta didik (2014), kasus wasting/kurus tingkat SD/MI tertinggi adalah wilayah kerja Puskesmas II Sumbang yaitu 43,2\% siswa. SD Negeri 01 Limpakuwus di Kecamatan Sumbang terdapat kasus wasting/kurus yaitu sebesar 8,3\%. Berdasarkan latar belakang diatas peneliti tertarik untuk mengetahui "Pengaruh Tingkat Konsumsi Energi, Protein, Lemak, dan Status Kecacingan Terhadap Status Gizi pada Siswa SD Negeri 01 Limpakuwus".

\section{METODE PENELITIAN}

Penelitian ini merupakan penelitian kuantitatif dengan pendekatan crosssectional. Sampel penelitian ini adalah siswa SD Negeri 01 Limpakuwus kelas IV sebanyak 44 orang, yang dipilih dengan teknik purposive sampling dengan menggunakan kriteria inklusi dan eksklusi. Jenis data yang digunakan terdiri dari data primer yang diperoleh dari wawancara menggunakan kuesioner dan data sekunder yang diperoleh dari data SD Negeri 01 Limpakuwus. Analisis data menggunakan analisis univariat, bivariat (rank spearman), dan multivariat (regresi logistik ganda).

\section{HASIL DAN PEMBAHASAN}

\section{Hasil}

\section{Karakteristik Responden}

Karakteristik responden dalam penelitian ini dilihat berdasarkan umur, jenis kelamin, jumlah anggota keluarga yang dapat dilihat pada Tabel 1.

Tabel 1. Karakteristik Responden Berdasarkan Umur, Jenis Kelamin, dan Jumlah Anggota Keluarga

\begin{tabular}{llcrr}
\hline No & Variabel & Kategori & Frekuensi (n) & Persentase (\%) \\
\hline 1. & Umur & 9 tahun & 7 & 15,9 \\
& & 10 tahun & 33 & 75 \\
& & 11 tahun & 4 & 9,1 \\
\hline 2. & Jenis kelamin & Laki-laki & 23 & 52,3 \\
& & Perempuan & 21 & 47,7 \\
\hline \multirow{2}{*}{3.} & \multirow{2}{*}{ Jumlah anggota keluarga } & Ideal $(\leq 4)$ & 24 & 54,5 \\
& & & 20 & 45,5 \\
\hline & Tidak ideal $(>4)$ & $\mathbf{4 4}$ & $\mathbf{1 0 0}$ \\
\hline
\end{tabular}

Sumber: Data Primer Terolah, 2016

Berdasarkan Tabel 1. diketahui bahwa sebagian besar responden berumur 10 tahun yaitu sebanyak 33 orang $(75,0 \%)$, berjenis kelamin lakilaki sebanyak 23 orang $(52,3 \%)$, dan memiliki jumlah anggota keluarga ideal sebanyak 24 orang $(54,5 \%)$.

\section{Hasil Analisis Univariat}

Berdasarkan hasil penelitian dengan wawancara kuesioner dan recall 
konsumsi makanan 2x24 jam dapat

frekuensi masing-masing variabel dilakukan analisis univariat. Distribusi penelitian dapat dilihat pada Tabel 2 .

Tabel 2. Distribusi Responden Berdasarkan Variabel-Variabel

\begin{tabular}{lllrr}
\hline No & Variabel & \multicolumn{1}{c}{ Kategori } & Frekuensi (n) & Persentase (\%) \\
\hline 1. & Tingkat konsumsi & Energi lebih & 1 & 2,3 \\
& energi & Energi normal & 3 & 6,8 \\
& & Energi kurang & 13 & 29,5 \\
& & Energi sangat kurang & 27 & 61,4 \\
\hline 2. & Tingkat konsumsi & Protein lebih & 3 & 6,8 \\
& protein & Protein normal & 5 & 11,4 \\
& & Protein kurang & 6 & 13,6 \\
& & Protein sangat kurang & 30 & 68,2 \\
\hline 3. & Tingkat konsumsi & Lemak lebih & 2 & 4,5 \\
& lemak & Lemak normal & 2 & 4,5 \\
& & Lemak kurang & 4 & 9,1 \\
& & Lemak sangat kurang & 36 & 81,8 \\
\hline 4. & Status kecacingan & Tidak terinfeksi & 21 & 47,7 \\
& & Terinfeksi & 23 & 52,3 \\
\hline 5. & Status gizi & Gemuk & 5 & 11,4 \\
& & Normal & 30 & 68,2 \\
& & Kurus & 7 & 15,9 \\
& & Sangat kurus & 2 & 4,5 \\
\hline & Total & & $\mathbf{4 4}$ & $\mathbf{1 0 0}$ \\
\hline
\end{tabular}

Sumber: Data Primer Terolah, 2016

Berdasarkan Tabel 2. diketahui

bahwa sebagian besar responden

memiliki tingkat konsumsi energi yang termasuk dalam kategori energi sangat kurang sebanyak 27 responden $(61,4 \%)$, sebagian besar responden memiliki tingkat konsumsi protein yang termasuk dalam kategori protein sangat kurang sebanyak 30 responden $(68,2 \%)$, sebagian besar responden memiliki tingkat konsumsi lemak yang termasuk dalam kategori lemak sangat kurang sebanyak 36 responden $(81,8 \%)$, sebagian besar responden mengalami kecacingan sebanyak 23 responden $(52,3 \%)$, dan sebagian besar responden memiliki status gizi yang termasuk dalam kategori normal sebanyak 30 responden $(68,2 \%)$.

\section{Hasil Analisis Bivariat}

Hasil analisis antar variabel pada siswa SDN 01 Limpakuwus dapat dilihat pada Tabel 3.

Tabel 3. Hubungan Antar Variabel-Variabel

\begin{tabular}{cccccc}
\hline No & Variabel & Jumlah (n) & Nilai Korelasi & p-value & $\boldsymbol{\alpha}$ \\
\hline 1. & $\begin{array}{c}\text { Tingkat Konsumsi Energi } \\
\text { Status Gizi }\end{array}$ & 44 & $-0,562$ & 0,000 & 0,05 \\
\hline 2. & $\begin{array}{c}\text { Tingkat Konsumsi Protein } \\
\text { Status Gizi }\end{array}$ & 44 & $-0,571$ & 0,000 & 0,05 \\
\hline 3. & $\begin{array}{c}\text { Tingkat Konsumsi Lemak } \\
\text { Status Gizi }\end{array}$ & 44 & $-0,403$ & 0,007 & 0,05 \\
\hline
\end{tabular}




\begin{tabular}{|c|c|c|c|c|c|}
\hline 4. & $\begin{array}{c}\text { Status Kecacingan } \\
\text { Status Gizi }\end{array}$ & 44 & $-0,068$ & 0,661 & 0,05 \\
\hline
\end{tabular}

Berdasarkan Tabel 3. diketahui bahwa terdapat hubungan antara tingkat konsumsi energi dengan status gizi (pvalue $<0,05)$, terdapat hubungan antara tingkat konsumsi protein dengan status gizi ( $\mathrm{p}$-value $<0,05)$, terdapat hubungan antara tingkat konsumsi lemak dengan status gizi ( $\mathrm{p}$-value $<0,05)$, dan tidak terdapat hubungan antara status

kecacingan dengan status gizi (p-value $>0,05)$.

\section{Hasil Analisis Multivariat}

Variabel yang dimasukkan
dalam analisis multivariat adalah
variabel yang pada analisis bivariat
mempunyai nilai $\mathrm{p}<0,25$ (Dahlan,
2008). Adapun variabel-variabel
tersebut seperti Tabel 4 .

Tabel 4. Model Akhir Hasil Analisis Regresi Logistik Ganda dengan Metode Backward

\begin{tabular}{cccccc}
\hline No & Variabel & B & Sig & RP & 95\% CI \\
\hline 1. & Tingkat Konsumsi Energi & $-20,089$ & 0,999 & 5,832 & - \\
\hline 2. & Tingkat Konsumsi Protein & 0,693 & 0,571 & 2,000 & $0,172-23,251$ \\
\hline $3 .$. & Tingkat Konsumsi Lemak & 2,833 & 0,022 & 17,000 & $1,506-191,922$ \\
\hline \multicolumn{7}{c}{ Constant } & $-1,099$ & 0,341 & & \\
\hline
\end{tabular}

Sumber: Data Primer Terolah, 2016

Berdasarkan Tabel 4. diketahui bahwa variabel terdapat satu variabel independen yang memiliki pengaruh terhadap status gizi yaitu tingkat konsumsi lemak $(\mathrm{p}=0,022)$ yang berarti memiliki nilai $\mathrm{p} \leq 0,05$, maka dapat dinyatakan bermakna secara statistik atau ada pengaruh yang signifikan antara variabel independen (tingkat konsumsi lemak) dengan status gizi pada siswa SD Negeri 01 Limpakuwus Kecamatan Sumbang.

\section{Pembahasan}

\section{Variabel yang Berpengaruh Terhadap Status Gizi}

Pengaruh Tingkat Konsumsi Lemak Terhadap Status Gizi

Analisis bivariat menunjukkan nilai $p=0,007$ menginterpretasikan bahwa terdapat hubungan antara tingkat konsumsi lemak dengan status gizi. Begitu pula dengan analisis multivariat, hasil uji regresi logistik ganda menunjukkan nilai $p=0,022$, hal ini 
membuktikan bahwa terdapat pengaruh secara statistik antara tingkat konsumsi lemak terhadap status gizi anak sekolah dasar di SD Negeri 01 Limpakuwus Kecamatan Sumbang Kabupaten Banyumas. Hasil penelitian sejalan dengan penelitian Ratnasari (2015), bahwa terdapat hubungan yang signifikan antara tingkat konsumsi lemak dengan status gizi lebih pada siswa SD Negeri 02 Kranji.

Berdasarkan hasil penelitian yang telah dilaksanakan di SD Negeri 01 Limpakuwus menunjukkan bahwa asupan lemak rata-rata perhari yaitu 34,2 gram dengan asupan lemak terendah yaitu 13,05, hal ini menunjukkan bahwa asupan lemak pada siswa SD Negeri 01 Limpakuwus masih sangat kurang dari AKG untuk orang Indonesia tahun 2013.

Pengaruh tingkat konsumsi lemak terhadap status gizi dikarenakan fungsi lemak dalam tubuh sebagai pembangun atau pembentuk susunan tubuh manusia (Yuniastuti, 2008). Penelitian Chunming (2000) menyatakan bahwa asupan lemak yang rendah akan berpengaruh terhadap status gizi anak di China. Kekurangan lemak pada seseorang, dapat menimbulkan pengurangan ketersediaan energi, karena energi harus terpenuhi maka terjadilah katabolisme atau perombakan protein, cadangan lemak yang semakin berkurang akan sangat berpengaruh terhadap penurunan berat badan (Marsetyo dan Kartasaputra, 2003).

Variabel yang Tidak Berpengaruh Terhadap Status Gizi

\section{Pengaruh Tingkat Konsumsi Energi} Terhadap Status Gizi

Analisis bivariat menunjukkan nilai $p=0,000$ menginterpretasikan bahwa terdapat hubungan antara tingkat konsumsi energi dengan status gizi. Namun, pada analisis multivariat hasil uji regresi logistik ganda pada analisis multivariat menunjukkan nilai $p=0,999$, hal ini membuktikan bahwa tidak ada pengaruh secara statistik antara tingkat konsumsi energi dengan status gizi anak sekolah dasar di SD Negeri 01 Limpakuwus Kecamatan Sumbang Kabupaten Banyumas. Hasil penelitian ini sesuai dengan penelitian Regar dan Sekartini (2013) yang menyatakan bahwa tidak terdapat hubungan antara asupan energi dengan status gizi anak.

Berdasarkan hasil penelitian yang telah dilaksanakan di SD Negeri 
01 Limpakuwus menunjukkan bahwa asupan energi rata-rata perhari yaitu 1130,45 kkal dengan asupan energi terendah yaitu 384,1 kkal, hal ini menunjukkan bahwa asupan energi pada siswa SD Negeri 01 Limpakuwus masih sangat kurang dari AKG untuk orang Indonesia tahun 2013. Banyaknya responden yang memiliki tingkat konsumsi energi sangat kurang disebabkan asupan konsumsi energi kurang dari yang dibutuhkan oleh tubuh, kurangnya variasi makanan dan frekuensi makan responden dan sebagian besar responden mengkonsumsi makanan yang hampir sama dalam satu hari.

Tidak adanya pengaruh antara kedua variabel dapat terjadi karena adanya cadangan energi yang dimiliki seseorang yang tersimpan dalam bentuk glikogen. Glikogen adalah salah satu bentuk penyimpanan dari kalori berlebih yang ada dalam tubuh, sebagai cadangan energi yang digunakan tubuh saat kekurangan energi (Sudjadi, 2007).

Pengaruh Tingkat Konsumsi Protein Terhadap Status Gizi

Analisis bivariat menunjukkan nilai $p=0,000$ menginterpretasikan bahwa terdapat hubungan antara tingkat konsumsi protein dengan status gizi. Namun, pada analisis multivariat hasil uji regresi logistik ganda menunjukkan nilai $p=0,580$, hal ini membuktikan bahwa tidak ada pengaruh secara statistik antara tingkat konsumsi protein dengan status gizi anak sekolah dasar di SD Negeri 01 Limpakuwus Kecamatan Sumbang Kabupaten Banyumas. Hasil penelitian ini sejalan dengan penelitian Yulni $d k k$ (2013) yang menyatakan tidak terdapat pengaruh antara tingkat konsumsi protein dengan status gizi berdasarkan indikator IMT/U.

Berdasarkan hasil penelitian yang telah dilaksanakan di SD Negeri 01 Limpakuwus menunjukkan bahwa asupan protein rata-rata perhari yaitu 33,76 gram dengan asupan protein terendah yaitu 13,85 gram, hal ini menunjukkan bahwa asupan protein pada siswa SD Negeri 01 Limpakuwus masih sangat kurang dari AKG untuk orang Indonesia tahun 2013.

Protein merupakan zat gizi yang paling erat hubungannya dengan prosesproses kehidupan. Konsumsi protein yang cukup akan mampu melakukan fungsinya untuk proses pertumbuhan. Ketidaksesuaian hasil penelitian dengan teori tersebut disebabkan karena 
berdasarkan rata-rata konsumsi protein, sebagian besar anak lebih banyak mengkonsumsi protein nabati dibandingkan protein hewani (Sulastri, 2012).

\section{Pengaruh Status Kecacingan Terhadap Status Gizi}

Analisis bivariat menunjukkan nilai $\quad p=0,661$ menginterpretasikan bahwa tidak terdapat hubungan antara status kecacingan dengan status gizi. Begitu pula pada analisis multivariat didapatkan hasil bahwa status kecacingan responden tidak berpengaruh terhadap status gizi anak sekolah dasar di SD Negeri 01 Limpakuwus Kecamatan Sumbang Kabupaten Banyumas. Hasil penelitian ini sejalan dengan penelitian Renanti $d k k$ (2015), yang menyatakan bahwa tidak terdapat hubungan secara statistik antara indeksi cacingan dengan status gizi.

Berdasarkan hasil pengamatan di laboratorium diperoleh tingkat status kecacingan siswa SD Negeri 01 Limpakuwus termasuk pada infeksi ringan pada sampel fases yang diperiksa, hal tersebut mengakibatkan tidak adanya hubungan antara status kecacingan dengan status gizi karena masih tergolong pada jenis infeksi sangat ringan. Menurut Arisman (2004) infeksi kecacingan yang masih tergolong ringan tidak menyebabkan penderita mengalami gejala mual hingga muntah yang dapat menyebabkan berkurangnya asupan zat gizi yang dapat diserap oleh tubuh.

Berdasarkan hasil penelitian di lapangan masih ada responden yang mempunyai perilaku $\mathrm{BAB}$ di kebun atau sungai (18,2\%). Menurut penelitian Fitri $d k k$ (2012) hasil observasi di lapangan menunjukkan mayoritas responden $\mathrm{BAB}$ ke pancuran/sungai dimana perilaku tersebut termasuk variabel yang mempengaruhi terjadinya infeksi kecacingan. Faktor risiko lain yang ditemukan di lapangan yaitu masih rendahnya konsumsi obat cacing dalam jangka waktu 6 bulan terakhir $(47,7 \%)$. Shan et al (2004) menyebutkan edukasi kecacingan yang disertai dengan pemeriksaan fases dan pemberian obat cacing dapat merubah perilaku sehingga dapat menurunkan angka kecacingan murid sekolah di China.

\section{SIMPULAN DAN SARAN}

\section{Simpulan}


Responden yang memiliki tingkat konsumsi energi sangat kurang sebanyak $61,4 \%$, sebanyak $68,2 \%$ responden memiliki tingkat konsumsi protein yang termasuk kategori sangat kurang, sebanyak 81,8\% responden memiliki tingkat konsumsi lemak yang termasuk kategori sangat kurang, sebanyak $52,3 \%$ responden mengalami kecacingan, dan sebanyak $68,2 \%$ responden memiliki status gizi yang termasuk kategori normal. Ada hubungan antara tingkat konsumsi energi, protein, lemak dengan status gizis. Tidak ada hubungan antara status kecacingan dengan status gizi. Faktor yang paling berpengaruh terhadap status gizi di SD Negeri 01 Limpakuwus adalah tingkat konsumsi lemak.

\section{Saran}

Menambah jumlah asupan makanan yang dikonsumsi dan memenuhi kebutuhan energi, protein, lemak harian, seperti kacang-kacangan, biji-bijian, daging, ayam, ikan segar, susu, sayur dan buah. Menjadikan kantin sekolah menjadi kantin sehat dengan cara menyediakan jajanan yang sehat dan bergizi.

\section{DAFTAR PUSTAKA}

Arisman, 2004, Gizi dalam Daur Kehidupan: Buku Ajar Ilmu Gizi, Buku Kedokteran EGC, Jakarta.

Chunming, C., Fat Intake and Nutritional Status Of Children in China, The American Journal of Clinical Nutrition, Vol 72: No 5 1368-1372.

Dinkes Kabupaten Banyumas, 2014, Profil Kesehatan Kabupaten Banyumas Tahun 2014, Dinas Kesehatan Kabupaten Banyumas, Purwokerto.

Fitri, J., Saam, Z., dan Hamidy, MY., 2012, Analisis Faktor-Faktor Risiko Infeksi Kecacingan Murid Sekolah Dasar di Kecamatan Angkola Timur Kabupaten Tapanuli Selatan Tahun 2012, Jurnal Ilmu Lingkungan, Vol 6: Nomor 2.

Kemenkes R.I., 2013, Kemenkes Berkomitmen Eliminasi Filariasis dan Kecacingan, http://www.depkes.go.id, diakses 16 Mei 2016.

Marsetyo., dan Kartasaputra, 2003, Ilmu Gizi: Korelasi Gizi, Kesehatan dan Produktivitas Kerja. Rineka Cipta, Jakarta.

Pahlevi, E, A., 2012, Determinan Status Gizi Pada Anak Sekolah Dasar, Jurnal Kesehatan Masyarakat, ISSN 1858-1196. 
Purnamasari, D, A., Dardjito, E., dan Titin, 2014, Hubungan Tingkat Konsumsi Protein dan Kalsium Dengan Status Gizi Pada Anak Sekolah, Jurnal Kesmas Indo, Vol 7: ISSN 20859929

Ratnasari, D., 2015, Hubungan Tingkat Konsumsi Gizi, Pola Makan Fast Food dan Aktivitas Fisik Dengan Status Gizi Lebih Pada Siswa Renanti, M.R., Rusjdi, R.S., dan Elmatris, Y.S., 2015, Hubungan Infeksi Soil Transmitted Helminth dengan Status Gizi pada Murid SDN 29 Purus Padang, Jurnal Kesehatan Andalas, Vol 4:No 2.

Riset Kesehatan Dasar, 2013, Badan Penelitian dan Pengembangan Kesehatan, Kementerian Kesehatan Republik Indonesia, Jakarta.

Shan., Jun., Xiang., Ping., Hay., dan Jones, 2004, Creating health-promoting schools in rural China: A project
Sekolah Dasar, Skripsi, Prodi Ilmu Gizi Univeritas Jenderal Soedirman, Purwokerto.

Regar, E., dan Sekartini, R., 2013, Hubungan Kecukupan Asupan Energi dan Makronutrien dengan Status Gizi Anak Usia 5-7 Tahun di Kelurahan Kampung Melayu, Jakarta Timur Tahun 2012, Jurnal Kesehatan Indonesia, Vol 1: No 3. started from deworming, Health Promotion Int, Vol 15: No 3: 197206.

Sulastri, D., 2012, Faktor Determinan Kejadian Stunting pada Anak Usia Sekolah Di Kecamatan Lubuk Kilangan Kota Padang, Majalah Kedokteran Andalas, Vol 36: No.1 45;50.

UNICEF, 1998, The State on the World Children, Oxford University Press.

Waryana, 2010, Gizi Reproduksi, Pustaka Rihama, Yogyakarta. 